\title{
Migration policy under the coalition government
}

\author{
David Robinson* \\ Sheffield Hallam University
}

\begin{abstract}
In recent years, popular and public debate on migration has become ever more trenchant. The hostile tone of debate has provided the coalition government with a legitimate basis upon which to pursue reform of the immigration system aimed at reducing net migration 'from hundreds of thousands to tens of thousands' and limiting the rights of migrants in the UK. This article reviews these reforms and considers the likelihood of the government meeting its target of reducing net migration to below 100,000 . Finally, a series of neglected issues demanding the urgent attention of migration policy are outlined.
\end{abstract}

Keywords: migration, asylum, coalition government, UK.

\section{Introduction}

The last 20 years have witnessed migration on a scale unparalleled in UK history. More than seven million people migrated to the UK between 1999 and 2011 (Hawkins, 2013). Net migration increased from an annual average of 37,000 in the period 1991 to 1995 to an annual average of 201,000 in the period 2008 to 2012 . Heated debate has surrounded this new phase of migration. Public perception has hardened around the view that society is paying a heavy price for the increased inflow of migrants. Press and media coverage has become unremittingly negative. Migrants are portrayed as bogus or illegal and their motives and actions questioned. Analysis of every article that mentioned 'immigrants', 'migrants', 'asylum seekers' and 'refugees' from 20 daily and Sunday newspapers over the three full years 2010-2012 (over 58,000 articles and 43 million words) found that by far the most common descriptor of immigrants across all newspaper types was 'illegal' and the most common description of asylum seekers was 'failed' (Migration Observatory, 2013). In 2013, 38 per cent of the population considered immigration to be one of the most worrying issues facing the UK, compared to less than five per cent in the mid-1990s (IPSOS MORI, 2013).

Political discourse on migration has also assumed an increasingly shrill tone in recent years. Links have been drawn between immigration and various social ills. The Prime Minister has blamed a "frightening" decade of "lax immigration" for putting too much pressure on communities and concurred with the suggestion that immigrants are a "constant drain" on public services (Swinford, 2013). He has talked about the "link 
between uncontrolled immigration and mass welfare dependency", arguing that immigrants have taken jobs from British workers and that to get people back to work we need to cap economic migration (Cameron, 2013). Never mind that the UK has never had uncontrolled immigration, that evidence about foreign workers taking British jobs is far from clear-cut or that migrants contribute far more in taxes than they receive in benefits and services. Immigration has been portrayed as "out of control", resulting in the country becoming awash with bogus asylum seekers and illegal migrants securing access to jobs and services at the expense of British citizens.

The relentlessly negative narrative dominating popular and political debate on migration has provided the coalition government with a legitimate basis on which to pursue a draconian migration policy focused on tightening the border and applying steady downward pressure on routes to long-term immigration (Green, 2010; 2012; May, 2010). This paper reviews the resulting reforms introduced since May 2010. Discussion begins by summarising key developments in migration policy. Government success delivering against the stated target of reducing net migration to less than 100,000 is then reviewed. Finally, a number of priorities currently neglected by contemporary policy but demanding urgent attention are spotlighted.

\section{'Bearing down on migration': Reform of the immigration system since May 2010}

The coalition government is unequivocal in its assertion that numbers matter and that the 'right number' for net migration is less than one hundred thousand. ${ }^{1}$ No clear explanation has been provided for why net migration of less than 100,000 is right and more than 100,000 is wrong. Neither is it clear what balance government is aiming to strike between temporary migration and permanent immigration or what the social and economic costs and benefits of its approach might be. The lack of reasoning has not stopped various reforms to the immigration system being introduced through changes to immigration rules and secondary legislation in a bid to reduce net migration to below 100,000 .

\section{Migrant workers}

Government has concentrated its efforts to reduce net migration from hundreds of thousands to tens of thousands on limiting the number of non-EAA ${ }^{2}$ nationals entering and remaining in the UK. An annual limit on the number of non-EEA migrants admitted to work in the UK came into effect in April 2011 for different visa categories or Tiers. To summarise:

- Tier 1 relates to 'high-value migrants' from outside the EEA and covers entry of entrepreneurs, investors and the small number of people who come under the 'exceptional talent' visa. Whilst the eligibility criteria and conditions attached to Tier 1 Investor and Entrepreneur visas were relaxed, a cap of 1,000 per annum was placed on the exceptional talent visa category for internationally recognised scientists, academics and artists was capped and graduate entrepreneur visas granted to international graduates to remain in the UK to develop their ideas. Meanwhile, the Tier 1 Post-Study Work category, which allowed foreign students who had studied in the UK to live and work in the UK following graduation for two years without the need for a sponsor was withdrawn. The Tier 1 general visa category which enabled highly skilled migrants to enter the UK without a job offer was also closed to new applicants. 
- Tier 2 is for 'skilled workers' from outside the EEA with a job offer in the UK. A limit of 20,700 was placed on the Tier 2 (general) visa category for skilled nonEEA workers with a firm offer of a job (now limited to a 'graduate level' job). There was also a reduction in the number of jobs listed on the 'shortage occupation' list, for which there is deemed to be not enough resident workers to fill the available jobs in that particular occupation. Minimum annual salary thresholds for Tier 2 (general) visas were also updated and from 2016 migrants will have to be earning at least $£ 35,000$ per annum to qualify for a visa.

- Tier 3 was designed for low-skilled workers filling specific temporary labour shortages. No visas have been granted under this scheme since it was introduced in 2008 and in March 2013 the Prime Minister announced that the Tier was to be shut down.

- Tier 4 is for students aged over 16 from outside the EEA who wish to study in the UK. Applicants must have a place at a registered UK educational establishment before they can apply. International students represent the largest proportion of non-EU net migration. The coalition government has introduced various additional measures and changes to this Tier. These include: an increase in the level of competency in English language for those coming to study at undergraduate level and above; a requirement that students sign a declaration that the funds they will be drawing on to support their studies are genuinely available; work during term time and work placements is restricted to international students studying at a 'recognised body' (universities) or a publiclyfunded further education college; only postgraduate students studying for longer than twelve months, or government-sponsored students, are allowed to sponsor dependents; Tier 4 visa holders are restricted to maximum five years of study on courses at degree level and above (with some exceptions); Tier 1 (Post-study work) route closed to new applicants, the Tier 1 (Graduate Entrepreneur) route created for up to 1,000 graduates, and upon completion of study students can also apply for a Tier 2 visa if they have a graduate level job offer of at least $£ 20,000$ per year from an employer who is a licensed sponsor.

\section{Family migration}

New eligibility criteria have also been introduced for non-EAA migrants joining family in the UK. Since November 2010 people applying for leave to enter or remain as the spouse or partner of someone settled in the UK have been required to provide evidence of their basic command of English by passing a UKBA-approved English language test. In July 2012, a wide-ranging set of reforms to family-related immigration categories came into effect. British citizens/settled persons wishing to sponsor their non-EEA national spouse/partner to join them in the UK must now evidence a minimum gross annual income of $£ 18,600$. In addition, new foreign spouses/partners must wait longer before they become eligible to apply for permanent settlement in the UK (five years rather than two as previously). A new approach to assessing the 'genuineness' of the relationship has also been introduced. The financial requirement has been challenged in the courts through judicial review. In the meantime, applications that are affected are not being processed (Gower and Hawkins, 2013). Finally, more restrictive eligibility criteria have been introduced for adult dependent relatives of British citizens or settled persons who wish to settle in the UK (Gower, 2012).

\section{Asylum}

The UK remains a signatory to the UN Convention on Refugees and is bound by a moral and legal duty to protect individuals who have fled persecution because of their race, 
religion, nationality or membership of a particular social or political group. People therefore continue to have the right to claim asylum in the UK and be entitled to the full protection of the law whilst their claim is being considered; in the year ending March 2013, 6,596 applications were granted asylum in the UK. Government attention has focused on trying to improve the asylum system and speed up the handling of cases. Various pilot schemes have been launched and a new set of performance indicators have been introduced against which to assess effectiveness of the system. Work has continued reviewing and trying to conclude unresolved asylum cases. However, by the fourth quarter of 2012, the UKBA was still case-working 33,500 backlog asylum applications (Home Affairs Select Committee, 2013).

The coalition agreement also committed the government to ending immigration detention of children, following concerns about the practice raised by the Children's Commissioner for England. In response, a new process for enforcing the removal of families refused permission to remain in the UK was introduced. Families with children are no longer detained in Immigration Removal Centres before removal from the UK. They may be held, however, for up to a week in secure 'pre-departure accommodation', which was opened in August 2011 and accommodates up to nine families and has onsite welfare services provided by Barnardo's. The Government has been commended for closing the Yarl's Wood family unit, where families and children were previously detained for an average of 14 days. However, it has been argued that the new predeparture accommodation is a detention centre in all but name (Gentlemen, 2011). The government's commitment to ending the detention of children for immigration control has also come under scrutiny in relation to the continued detention of children in short-term holding facilities at UK ports of entry (see Gower, 2013).

\section{EU migration}

The government has little control over one of the largest migration streams into the UK. More than 35 per cent of all immigration to the UK in the year ending September 2012 was accounted for by EU citizens. Unless the UK leaves the EU or renegotiates the terms of its membership and withdraws from the single market and the associated commitment to the free movement of labour, the only control government is able to exercise over EU migration relates to the freedom of movement rights of citizens of new EU states. Invoking this power, the government has exercised its right to enforce transitional restrictions on the free movement rights of Croatian workers for up to seven years, following their accession to the EU in 2013.

The only other notable development since 2010 in relation to EU migration is the increasing interest being voiced in further restricting the rights of EU nationals to welfare benefits within the UK. The UK already employs a "right-to-reside" formula when deciding if non-British EU citizens resident in the UK are eligible for various benefits. The legality of this formula is being challenged in court by the European Commission. However, the Prime Minister has indicated that plans are being drawn up to further curtail the rights of EU citizens living in the UK. According to the Prime Minister, "one of the advantages of British membership of the EU is that British people go and live and work in other countries. But I think there is a problem with people living [here] and not working" (Kirkup, 2013). These tighter controls are intended to be part of a new UK-EU relationship that the Prime Minister is hoping to be able to put to the British people in a referendum on EU membership in the event of a Conservative victory at the 2015 general election. However, the government has been challenged by the European Commission and the House of Lords European Union committee to provide any evidence of social benefit tourism to substantiate the claims it is making about the need for such reforms (House of Lords European Union Committee, 2013). 


\section{Permanent residency and citizenship}

Arguing that it has been too easy for people to move from temporary residence to permanent settlement in the UK, the coalition government has revised eligibility criteria and introduced additional requirements. Initial changes included the requirement that applicants for settlement be free from any unspent convictions at the time of application. Additional requirements have also been introduced for non-EEA workers and their spouses, as discussed above. Subsequently, a more demanding knowledge of language and life in the UK requirement was introduced for people applying for permanent settlement or citizenship. From 28 October 2013, applicants for settlement or naturalisation as a British citizen will need to meet the knowledge of language and life requirement by passing the revised life in the UK test and having a speaking and listening qualification in English at B1 Common European Framework of Reference for Languages or higher, or its equivalent (summarised as the ability to express oneself in a limited way in familiar situations and to deal in a general way with non-routine information).

The Minister for Immigration announced that the test was "part of our work to help ensure migrants are ready and able to integrate into British society and forms part of our changes which have broken the automatic link between temporary and permanent migration" (Harper, 2013). However, the new test appears to be more of a rationing device than an integration tool. Applicants are no longer required to know about practicalities of life in the UK, such as the NHS, educational qualifications, the subjects taught in schools, how to report a crime or contact an ambulance and other everyday knowledge, but instead are required to memorise a series of facts, such as the age of Big Ben and the height of the London Eye (in feet and metres) (Brooks, 2013).

\section{Governance of the immigration system}

Good governance of the immigration system is vital if the public are to trust government action (Somerville, 2011). However, basic principles of accountability, transparency and targeted action that underpin effective governance structures have been too frequently absent from the UK immigration system. Speaking to the Home Affair Select Committee in 2006, the then Home Secretary, John Reid, admitted that "in the wake of the problems of mass migration that we have been facing our system is not fit for purpose. It is inadequate in terms of its scope; it is inadequate in terms of its information technology, leadership, management, systems and processes." In an attempt to address these failings, the UK Border Agency (UKBA) was formed in 2008 to serve as the border control agency of the UK Government. However, the immigration system continued to perform poorly in several areas, such as tackling the asylum and immigration backlog, dealing with foreign national offenders when they are released from prison, and processing in-country visa renewals (Home Affairs Committee, 2013). In 2011, following differences of understanding between Ministers and UKBA officials about a pilot of risk-led border controls, the Home Secretary took control for the border control function away from UKBA and announced the creation of a new Border Force. Following a damning report on the performance of the UKBA by the Home Affairs Select Committee, the Home Secretary announced in 2013 that the UKBA was to be abolished, commenting that "the performance of what remains of UKBA is still not good enough. The Agency struggles with the volume of its casework, which has led to historical backlogs running into the hundreds of thousands; the number of illegal immigrants removed does not keep up with the number of people who are here illegally; and while the visa operation is internationally competitive, it could and should get better still." As a result, the original functions of the UKBA are now divided between four Home office units (House of Commons Homes Affairs Select Committee, 2013): 
- Border Force - a law enforcement command within the Home Office which carries out immigration and customs controls for people and goods entering the UK

- UK Visas and Immigration - handling migration casework and customer contact, visas, asylum casework, appeals, and business, growth and premium services

- Immigration Enforcement - deals with removals and detention, operational intelligence, foreign national offenders and immigration crime

- Operational Systems Transformation - responsible for modernising immigration technology; performance, assurance and compliance; business strategy, analysis, design and change; and joint working across the immigration system.

Latest estimates suggest that the total number of immigration cases in backlog has reached over half a million $(502,000)$ (House of Commons Homes Affairs Select Committee, 2013).

\section{Migration in numbers since 2010}

The public appears to support the coalition government's aim of reducing immigration, but are sceptical about their ability to deliver it (Kellner, 2012). This scepticism is well placed. As already discussed, the government has limited control over EU migration or the number of people seeking asylum. Efforts to cut net migration have therefore focused on non-EEA migrants. At first sight, this approach appears to have reaped dividends for the government. Immigration fell from 589,000 in the year to June 2011 to 515,000 in the year to June 2012, and net migration fell from 247,000 in the year to June 2011 to 163,000 in the year to June 2012 (Gower and Hawkins, 2013). The largest fall in migrants with different reasons for migrating to the UK was among people migrating to study, which fell by 42,000 (18 per cent) in the year to June 2012 . There was also a fall in the number of people migrating for work $(21,000)$ and people migrating for family reasons $(17,000)$ (Gower and Hawkins, 2013). However, there are a number of reasons why this downward trend is unlikely to continue.

First, the impact of the large fall in student visa applications on net migration, which is almost certainly a result of changes to the student immigration rules in April 2012, is likely to be short-lived given that most students only stay in the UK for a short time, reduced immigration today resulting in reduced emigration two or three years down the line (Mulley, 2012). Second, the government has few options for further reducing nonEEA immigration. One of the few alternatives available is the introduction of a cap on intra-company transfers (the temporary transfer by a company of an employee to work in their UK office). These moves account for a relatively large proportion of skilled migration and were excluded from the cap that came into effect in 2012. However, such a cap would risk the ire of business, undermine government claims that the UK is 'open for business' and raise questions about impacts on economic performance. Third, although asylum claims are very low in historical terms, there is an upward trend in applications, in part, linked to fallout from the Arab spring and continuing troubles in the Middle East (Home Office, 2013). Fourth, the transitional controls on migrant workers from Bulgaria and Romania, following their accession to the EU in 2007, will be lifted in January 2014 resulting in an inevitable, if unpredictable, increase in the number of migrants arriving into the UK from these countries. Fifth, future progress towards meeting the new migration target is dependent upon patterns of EU migration, which are largely beyond the control of government. In 2012, trends in migration from the EU contributed toward the overall reduction in net migration; net migration from the 
EU fell from 81,000 in the year to September 2010 to 66,000 in the year to September 2012. This trend could just as easily reverse, particularly in the context of emerging economic growth in the UK and the continuing economic crisis in Eurozone countries. In short, patterns of immigration and emigration are unpredictable and largely outside the government's control, a fact illustrated by the rise in net migration to 176,000 in the year ending December 2012, an increase of 23,000 on the figure for the year to September 2012 (ONS, 2013).

\section{Neglected priorities}

The political imperative of the coalition government - to reduce net migration by capping non-EEA immigration - speaks directly to dominant themes of popular and political debate on migration and is undoubtedly popular. However, by defining numbers as the heart of the matter, it fails to face up to the reality that migration will continue to be a feature of life in Britain and serves to neglect a range of issues and challenges that urgently need to move onto the policy agenda. Key examples include:

- promoting integration - Government has been quick to blame migrants for not integrating into British society but slow to support the integration process. The Prime Minister has warned that immigrants unable to speak English or unwilling to integrate into British society have created a "kind of discomfort and disjointedness" that has disrupted communities across Britain (Cameron, 2011). Yet, central government has washed its hands of any responsibility for integration, asserting that the integration of migrants is an issue for local authorities (DCLG, 2012). Particularly concerning is the fact that free access to ESOL training (English for Speakers of Other Languages) has been limited to people on 'active' benefits, thereby excluding large numbers of migrants including full-time parents, people in low-paid employment, people with disabilities and older people. English language skills are fundamental to enabling migrants to operate independently and to begin to integrate into UK society (NIACE, 2009). The provision of free access ESOL training should therefore be a priority for migration policy.

- mediating the local impacts of migration - the scale and nature of contemporary migration has the potential to drive change at the neighbourhood level posing challenges for migrants, existing communities and service providers. Government has done little or nothing to help local communities manage these challenges. The Migrant Impacts Fund that provided funding for local community projects to manage the impacts of immigration has been terminated (Gower, 2010). Local services have been left to manage the challenges of responding to rapid population change and a shifting profile of local need, and deal with the tensions that sometimes arise between new arrivals and settled populations, all within the context of austerity and cuts. Migration has local impacts and government needs to step forward and help local communities manage these challenges. The alternative is to risk rising resentment and tensions.

- protecting the human rights of migrants - it is possible to point to aspects of policy where this is not currently not the case. These include the detention and enforced removal regime; the destitution that asylum seekers experience at every stage of the asylum process; and the difficulties people encounter challenging, what often turn out to be, specious decisions on immigration applications. There are also examples where policy is failing to tackle the exploitation of migrants, an obvious example being in the work place. The 
immigration system should protect, not compromise, the basic human rights of migrants.

These and other neglected priorities of a humane, fair and realistic migration policy are unlikely to find their way onto the policy agenda for as long as political discourse is dominated by moral panic and scapegoating, rather than measured discussion rooted in evidence of migration trends and associated experiences and consequences. Until such time, a far more attractive political strategy is likely to involve bringing forward ever more draconian measures. The new immigration bill would appear to encapsulate this approach, with its ambition of creating a more hostile environment for illegal migrants and limiting the rights of legal migrants, for example, to health care.

\section{Notes}

1 This ambition was spelt out in the Conservative Party Manifesto for the 2010 General Election and reiterated by the Home Secretary, Theresa May, in the House of Commons in November 2010 (HC Deb 23 Nov 2010, c169, Controlling Migration).

2 The European Economic Area (EEA) comprises all member states of the European Union plus Iceland, Liechtenstein and Norway.

* Correspondence Address: Professor David Robinson, CRESR, Unit 10, Science Park, Howard Street, Sheffield, S1 1WB. Email: d.robinson@shu.ac.uk.

\section{References}

Brooks, T. (2013) The 'Life in the United Kingdom' Citizenship Test. Is It Unfit for Purpose? http://thombrooks.info/Brooks_citizenship_test_report.pdf

Cameron, D. (2011) Speech on immigration to party members, 14 April. http://www.bbc.co.uk/news/uk-politics-13083781

Cameron, D. (2013) Plan for Britain's success. Speech by the Prime Minister. 10 June. https://www.gov.uk/government/speeches/plan-for-britains-success-speech-bythe-prime-minister

Gentlemen, A. (2011) Child detention: has the government broken its promise to end it? The Guardian, 17 October. http://www.theguardian.com/uk/2011/oct/17/childdetention-government-broken-promise

Gower, M. (2010) Migration Impacts Fund. House of Commons Library Standard Note (SN05725).

Gower, M. (2012) Changes to Immigration Rules for family members. House of Commons Library Standard Note (SN06353).

Gower, M. (2013) Ending child immigration detention. House of Commons Library Standard Note (SN05591).

Gower, M. and Hawkins, O. (2013) Immigration and asylum policy: Government plans and progress made. House of Commons Library Standard Note (SN05829).

Green, D. (2010) Immigration: Damian Green's speech to the Royal Commonwealth Society. 7 September 2010. https://www.gov.uk/government/speeches/ immigration-damian-greens-speech-to-the-royal-commonwealth-society

Green, D. (2012) Damian Green's speech on making immigration work for Britain. February 2012. https://www.gov.uk/government/speeches/damian-greensspeech-on-making-immigration-work-for-britain 
Harper, M. (2013) New Life in the UK test goes live. Home Office Press Release, 25 March. https://www.gov.uk/government/news/new-life-in-the-uk-test-goes-live--2

Hawkins, O. (2013) Migration Statistics. House of Commons Library Standard Note SN/SG/6077. http://www.parliament.uk/briefing-papers/SN06077

Home Office (2012) Immigration Statistics July - September 2012 http://www.homeoffice.gov.uk/publications/science-research-statistics/researchstatistics/immigration-asylum-research/immigration-q3-2012/

Home Office (2013) Asylum data tables immigration statistics April to June 2013. https://www.gov.uk/government/publications/tables-for-immigration-statisticsapril-to-june-2013

House of Commons Homes Affairs Select Committee (2013) Home Affairs Committee Fourth Report The work of the UK Border Agency (October-December 2012). http://www.publications.parliament.uk/pa/cm201314/cmselect/cmhaff/486/4 8602.htm

House of Lords European Union Committee (2013) Letter to mark Harper MP. http://www.parliament.uk/documents/lords-committees/eu-sub-com-b/Free MovementofWorkers/LtrtoMarkHarperMPre9124-13FreedomofMovement forWorkers040913.pdf

IPSOS MORI (2013) Economist/Ipsos MORI August 2013 Issues Index. http://www.ipsos-mori.com/researchpublications/researcharchive/3247/ Economistlpsos-MORI-August-2013-Issues-Index.aspx

Kellner, P. (2012) The perilous politics of migration YouGov. http://yougov.co.uk/news/2012/12/17/perilouspolitics-immigration/

Kirkup, J. (2013) David Cameron to curb EU migrants rights to benefits. The Telegraph, 6 September. http://www.telegraph.co.uk/news/uknews/immigration/1029 0427/David-Cameron-to-curb-EU-migrants-rights-to-UK-benefits.html

May, T. (2010) Immigration: Home Secretary's speech of 5 November 2010. https://www.gov.uk/government/speeches/immigration-home-secretarys-speechof-5-november-2010

Migration Observatory (2013) Migration in the News: Portrayals of Immigrants, Migrants, Asylum Seekers and Refugees in National British Newspapers, 20102012. Oxford University, http://www.migrationobservatory.ox.ac.uk/sites/files/ migobs/Report\%20-\%20migration\%20in\%20the\%20news.pdf.

Mulley, S. (2012) Migration Review 2012/2013. London: IPPR.

NIACE (2009) Refugees and asylum seekers in the UK: The challenges of accessing education and employment. National Institute of Adult Continuing Education. http://www.niace.org.uk/sites/default/files/91-refugees-and-asylum-seekers-inthe-uk.pdf

ONS (2013) Migration Statistics Quarterly Report, August 2013. London: Office for National Statistics.

Somerville, W. (2011) Immigration policy in the UK - challenges and priorities. In: Johnson, N. (ed.) Migration: Where Next? Developing a New Progressive Immigration Policy (p.8-19). London: Smith Institute.

Swinford, S. (2013) David Cameron: 'Immigration is constant drain on public services'. The Telegraph, 23 July, http://www.telegraph.co.uk/news/politics/ 10197738/David-Cameron-Immigration-is-constant-drain-on-public-services.html 